\title{
Pengaruh Pemberian Ekstrak Etanol Daun Dandang Gendis (Clinacanthus nutans (Burm F) Lindau) Terhadap Daya Analgesik Dan Gambaran Makroskopis Lambung Mencit
}

\author{
Maria Happy Christian Klau ${ }^{1}$, Rosa Juwita Hesturini ${ }^{1}$ \\ ${ }^{1}$ Institut Ilmu Kesehatan Bhakti Wiyata Kediri \\ Email: maria.happy@iik.ac.id
}

*corresponding author

Diterima : 16 April 2021

Direvisi : 29 April 2021

Publikasi : 20 Juni 2021

doi:10.52216/jfsi.v4i1.59

\begin{abstract}
Dandang gendis (Clinacanthus nutans (Burm f.) Lindau) is one of the plants used for as medication for various type of illness. One of its uses is as an analgesic drug. This study aims to determine the effect of dandang gendis leaf extract on the analgesic activity and macroscopic image of the stomach of white mice. This research was conducted using a completely randomized unidirectional pattern. The creature used as treatment subjects were separated into five groups consists of five individual each: group I as negative control mice who were only given $1 \% \mathrm{Na}$-CMC equivalent, group II as positive control was given acetosal $500 \mathrm{mg} / \mathrm{KgBB}$, group III was given extract treatment with a dose of $450 \mathrm{mg} / \mathrm{KgBB}$, group IV was treated with the extract at a dose of 500mg / KgBB, group $V$ was given an extract treatment at a dose of 550mg / $\mathrm{KgBB}$. All groups were given acetic acid induction as a mediator of pain. The results showed that the ethanol extract of Dandang Gendis leaves had an analgesic effect and was safe to use as an analgesic at a dose of $500 \mathrm{mg} / \mathrm{KgBB}$.
\end{abstract}

Keywords: Clinacanthus nutans (Burm f.) Lindau, Analgetic, Extract, Acetic acid inducer, wrinting test

\section{Intisari}

Dandang gendis (Clinacanthus nutans (Burm f.) Lindau) adalah salah satu tanaman yang digunakan untuk berbagai pengobatan di Indonesia. Salah satu kegunaannya adalah sebagai obat analgesik. Penelitian ini bertujuan untuk melihat pengaruh pemberian ekstrak daun dandang gendis terhadap daya analgesik dan gambaran makroskopis pada lambung mencit putih. Penelitian ini dilakukan dengan menggunakan acak lengkap pola searah. Hewan uji yang digunakan dibagi dalam 5 kelompok uji yang setiap kelompok terdiri dari 5 ekor: kelompok I sebagai kontrol negatif mencit yang hanya diberikan sejumlah ekuivalen $\mathrm{Na}-\mathrm{CMC} 1 \%$, kelompok II sebagai kontrol positif diberikan asetosal 500mg/KgBB, kelompok III diberi perlakuan ekstrak dengan dosis $450 \mathrm{mg} / \mathrm{KgBB}$, kelompok IV perlakuan ekstrak dengan dosis $500 \mathrm{mg} / \mathrm{KgBB}$, kelompok $V$ diberi perlakuan ekstrak dengan dosis 550mg/KgBB. Semua kelompok diberikan induksi asam asetat sebagai mediator nyerinya. Hasil penelitian menunjukkan bahwa ekstrak etanol daun Dandang Gendis memiliki efek memiliki efek analgesik dan aman digunakan sebagai analgesik dengan dosis $500 \mathrm{mg} / \mathrm{kgBB}$.

Kata kunci: Clinacanthus nutans (Burmf.) Lindau, Analgesik, Ekstrak, Induksi Asam Asetat, Wrinting test 


\section{Pendahuluan}

Salah satu gejala penyakit yang sering dialami oleh setiap orang adalah Nyeri. Nyeri merupakan suatu pengalaman sensoris dan emosional yang tidak nyaman yang berkaitan dengan adanya kerusakan jaringan aktual atau masih memiliki potensial untuk terjadi kerusakan dikemudian hari (Mashuri et al, 2020). Pengalaman ini tentunya berhubungan dengan proses yang sebenarnya terjadi diotak namun yang sering ditemukan justru cedera yang terjadi di syaraf tepi (Rustam \& Arifin, 2020).

Beberapa pengobatan sering dilakukan untuk tindakan pencegahan tingkat keparahan nyeri. Salah satu yang sering digunakan adalah analgesik yaitu asetosal. Banyak masyarakat menggunakan asetosal untuk mengurangi gejala nyeri, tanpa memperhatikan efek samping yang terjadi jika digunakan dalam jangka waktu yang lama. Efek samping penggunaan asetosal yang sering terjadi seperti mual, muntah serta kerusakan ginjal dan hati (Dipiro et al., 2015). Oleh karena itu perlu dicari alternatif pengobatan menggunakan tanaman herbal untuk meminimalisir terjadi efek samping merugikan yaitu menggunakan tanaman daun dandang gendis.

Daun Dandang Gendis (Clinacanthus nutans (Burm f.) Lindau) merupakan salah satu jenis tanaman herbal, di Indonesia masyarakat dapat memanfaatkan jenis tanaman ini untuk pengobatan tradisional, sebagai tindakan pencegahan maupun pengobatan terhadap berbagai jenis penyakit dan ditemukan terdistribusi di seluruh wilayah tropis termasuk Asia Tenggara dan Cina (Tambaru et al., 2019). Daun dandang gendis dilaporkan banyak memiliki khasiat sebagai penurun kadar glukosa darah (Dewinta et al., 2020), menghambat aktivitas alfa glucosidase (Murugesu et al., 2018) memiliki aktivitas sebagai antiinflamasi (Mai et al., 2016). Daun Dandang Gendis mengandung senyawa metabolit sekunder di antaranya Alkaloid, Triterpen, saponin dan Flavonoid (Wijaya et al., 2019). Flavonoid berkhasiat sebagai analgesik dengan mekanisme kerjanya menghambat kerja enzim siklooksigenase (Tamimi, Queljoe, \& Siampa, 2020). Penghambatan enzim siklooksigenase akan mengurangi produksi prostaglandin sehingga mengurangi rasa nyeri (Patel, 2010). Khasiat dari daun Dandang Gendis ini belum dibuktikan secara ilmiah dan masih dilaporkan penggunaannya secara empiris. Oleh karena itu penelitian ini bertujuan untuk melihat pengaruh pemberian ekstrak daun dandang gendis terhadap daya analgesik dan gambaran makroskopis pada lambung mencit putih.

\section{Metode Penelitian}

\subsection{Determinasi Tanaman}

Tanaman yang akan diteliti sebelum dikumpulkan untuk dijadikan sebagai sampel terlebih dahulu dilakukan determinasi. Determinasi dilakukan dengan tujuan untuk mengetahui kebenaran tanaman yang akan diteliti dan menghindari kesalahan dalam pengumpulan bahan serta menghindari kemungkinan tercampurnya tanaman yang akan diteliti dengan tanaman lain. Determinasi tanaman Dandang Gendis (Clinacanthus nutans (Burm f.) Lindau) dilakukan di Laboratorium Biologi Farmasi Institut Ilmu Kesehatan Bhakti Wiyata Kediri.

2.2. Pengumpulan Bahan Dan Pembuatan Serbuk Tanaman dandang Gendis diperoleh dari kecamatan Kepanjen Kidul Kota Blitar dalam keadaan segar. Daun dandang gendis yang dikumpulkan dicuci, dirajang dan dikeringkan dengan oven suhu $50^{\circ} \mathrm{C}$. Simplisia yang diperoleh dibuat serbuk.

2.3.Pembuatan Ekstrak

Simplisia herba dandang gendis diekstraksi dengan metode maserasi dengan pelarut polar, yaitu etanol $96 \%$ sebanyak 2,5 L selama 5 hari dan remaserasi selama 2 hari dengan etanol 96\% sebanyak 1,25 L. Hasil maserasi disaring dengan corong yang dialasi kain flanel kemudian di saring lagi dengan dialasi menggunakan kertas saring, kemudian diuapkan pada rotary evaporator (Buchi IA12).

\subsection{Penyiapan Hewan uji}

Hewan uji yang digunakan adalah mencit jantan (Mus musculus) yang berumur 3 bulan dengan berat badan berkisar antara 20-25 g. Jumlah mencit yang digunakan sebanyak 25 ekor. Mencit diadaptasi selama 1 minggu pada laboratorium Farmakologi IIK BW dan diberikan makanan standar, minuman dan pencahayaan pada suhu kamar. 


\subsection{Induksi Analgesik dan Pemeriksaan \\ Makroskopis Lambung}

Aktivitas analgesik ditentukan dengan cara mengamati jumlah geliat tiap mencit yang sebelumnya diberi perlakuan ekstrak dengan cara per oral, lalu diamati selama 30 menit kemudian diberikan larutan asam asetat secara intraperitoneal sebagai penginduksi nyeri.

Pengamatan aktivitas analgesik dilakukan menggunakan metode wrinting test. Setelah mencit diadaptasikan selama 7 hari, mencit dibagi ke dalam 5 kelompok $(n=5)$ yang terdiri dari kelompok 1 (kelompok kontrol negatif), kelompok 2 (kelompok kontrol positif), kelompok 3 (ekstrak $450 \mathrm{mg} / \mathrm{kgBB}$ ), kelompok 4 (kelompok ekstrak $500 \mathrm{mg} / \mathrm{kgBB}$ ), kelompok 5 (kelompok ekstrak $550 \mathrm{mg} / \mathrm{kgBB}$ ) kemudian diberi perlakuan sesuai kelompok masing-masing, setelah 30 menit, diinjeksi dengan asam asetat $0,6 \%$ secara intraperitoneal, diamati dan dicatat geliat setiap 5 menit sekali selama 30 menit. Selanjutnya dihitung $\%$ analgesik dengan rumus $=100 \%-(\mathrm{p} / \mathrm{k} \times 100 \%)$ dengan $\mathrm{p}$ merupakan jumlah kumulatif geliat mencit kelompok perlakuan dan $\mathrm{k}$ merupakan jumlah kumulatif geliat mencit kelompok kontrol negatif (Amellia \& Khumaidi, 2015)

Pemeriksaan makroskopis lambung dilakukan di laboratorium Farmakologi IIK BW dimana setelah 7 hari perlakuan, mencit dikorbankan dengan metode anastesi dengan menggunakan dietil eter. Hewan coba dibedah kemudian diambil organ lambung dan dibuka lengkung besar. Lambung dicuci dengan larutan $\mathrm{NaCl}$ fisiologis, kemudian direntangkan di atas papan gabus, dihitung jumlah ulkus yang terjadi dan ditentukan tingkat keparahan ulkus. Tingkat keparahan ulkus dihitung dengan menggunakan rumus $=\mathrm{J}+\mathrm{K}+$ (\% $\mathrm{I} / 10)$ dengan $\mathrm{J}$ merupakan rata-rata skor jumlah tukak tiap kelompok perlakuan, $\mathrm{K}$ merupakan ratarata skor keparahan tukak tiap kelompok perlakuan dan \%I merupakan persentase hewan yang terkena tukak dalam tiap kelompok.

\subsection{Analisis data}

Data pengamatan jumlah geliat dan indeks tukak lambung mencit tiap kelompok $(n=5)$ dibuat rata-rata dan disajikan dalam bentuk grafik. Hasilnya diuji secara statistik dengan menggunakan Uji kruskal wallis dan Mann whitney.

\section{Hasil dan Pembahasan}

3.1. Determinasi tanaman daun Dandang Gendis

Hasil determinasi tanaman yang dilakukan di Laboratorium Biologi Farmasi IIK BW Kediri menunjukkan bahwa sampel yang digunakan adalah benar tanaman daun dandang gendis dengan nama latin (Clinacanthus nutans (Burm f.) Lindau) dari famili Acanthaceae.

3.2. Skrining Fitokimia dan KLT Ekstrak Etanol Daun Dandang Gendis

Hasil ekstraksi serbuk simplisia daun dandang gendis sebesar 500 gram didapatkan berat ekstrak sebesar 54,651 gram dengan rendemen ekstrak sebesar $10,7 \%$. Setelah itu dilakukan skrining fitokimia dengan hasilnya dapat diliat pada tabel 1 . Uji flavonoid dan Tanin menunjukkan hasil yang positif sedangkan uji saponin dan alkaloid menunjukkan hasil yang negatif.

Tabel 1. Hasil skrining Fitokimia daun Dandang Gendis (Clinacanthus nutans (Burm f.) Lindau)

\begin{tabular}{|c|c|c|c|}
\hline Golongan senyawa & Literatur & Hasil Pengujian & Keterangan \\
\hline Flavonoid & $\begin{array}{l}\text { Warna lebih hitam jika } \\
\text { positif }\end{array}$ & Warna lebih hitam & + \\
\hline Saponin & $\begin{array}{l}\text { Terbentuknya } \\
\text { busa yang stabil }\end{array}$ & $\begin{array}{l}\text { Tidak terbentuk } \\
\text { busa }\end{array}$ & - \\
\hline Alkaloid & $\begin{array}{l}\text { Dragendorf: endapan putih, } \\
\text { coklat untuk wegner, jingga } \\
\text { untuk mayer }\end{array}$ & $\begin{array}{l}\text { Endapan berwarna, putih } \\
\text { untuk dragendorf, coklat } \\
\text { untuk wegner, jingga untuk } \\
\text { mayer }\end{array}$ & - \\
\hline Tanin & Warna coklat kehijauan & Warna coklat kehijauan & + \\
\hline
\end{tabular}


Hasil skrining fitokimia diperkuat dengan pengujian KLT untuk mengetahui kandungan senyawa dalam ekstrak etanol herbal daun Dandang Gendis. Hasil Uji KLT Flavonoid pada ekstrak Herba daun Dandang Gendis dengan fase gerak yang digunakan yaitu toluene : aseton : asam format dengan perbandingan $(6: 6: 1)$ dapat dilihat pada gambar 1 .

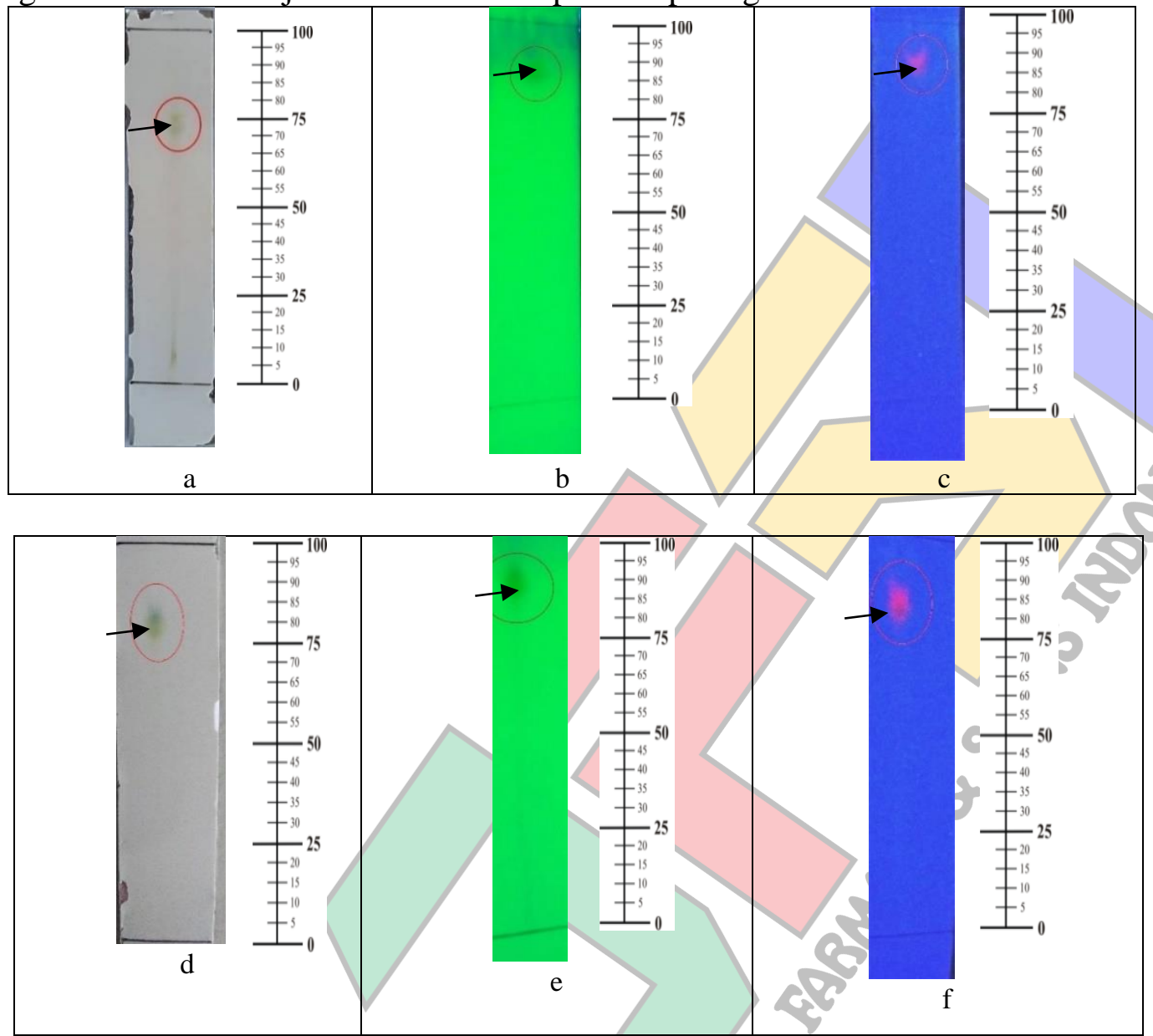

Gambar 1. Hasil pengujian KLT kandungan Flavonoid pada lampu UV 254 nm dan 366 nm

Keterangan :

a. Hasil KLT diamati di bawah sinar tampak sebelum diuapkan dengan ammonia

b. Hasil pengujian KLT di bawah UV $254 \mathrm{~nm}$ sebelum diuapkan dengan ammonia

c. Hasil pengujian KLT di bawah UV $366 \mathrm{~nm}$ sebelum diuapkan dengan ammonia

d. Hasil KLT diamati di bawah sinar tampak setelah diuapkan dengan ammonia

e. Hasil pengujian KLT di bawah UV $254 \mathrm{~nm}$ setelah diuapkan dengan ammonia

f. Hasil pengujian KLT di bawah UV $366 \mathrm{~nm}$ setelah diuapkan dengan ammonia

\subsection{Adaptasi Hewan uji dan Pengujian Aktivitas}

Analgesik

Hewan uji yang akan dilakukan pengujian aktivitas analgesik sebelumnya dilakukan adaptasi dengan lingkungan sekitar selama 7 hari tujuannya untuk memastikan agar hewan uji yang digunakan tetap dalam keadaan sehat dan memiliki aktivitas yang normal (Fadhilla, Adnyana, \& Chaniago, 2020). Hewan uji yang digunakan adalah mencit dengan bobot badan 20 gram yang berumur 3 bulan, dalam kondisi sehat dan tidak mengalami kelainan.

Setelah hewan uji dilakukan adaptasi selama 7 hari, hewan uji dibagi dalam 5 kelompok dan diberikan perlakuan sesuai kelompok masingmasing, setelah itu masing-masing kelompok perlakuan diinduksi nyeri dengan asam asetat secara intraperitoneal. Kemudian diamati dan dicatat geliat pada tiap ekor mencit setiap 5 menit selama 30 menit. Rata-rata pengamatan geliat tiap kelompok perlakuan dapat dilihat pada tabel 2 . 
Tabel 2. Rata-rata Pengukuran Geliat pada Mencit

\begin{tabular}{|c|c|c|c|c|c|c|}
\hline \multirow{2}{*}{$\begin{array}{l}\text { Kelompok } \\
\text { perlakuan }\end{array}$} & \multicolumn{6}{|c|}{ Jumlah geliat } \\
\hline & 5 menit & 10 menit & 15 menit & 20 menit & 25 menit & 30 menit \\
\hline $\begin{array}{l}\text { Kontrol } \\
\text { Positif (Asetosal } \\
\text { dosis } 500 \mathrm{mg} / \mathrm{kg} \text { ) }\end{array}$ & $0 \pm 0$ & $0 \pm 0$ & $0 \pm 0$ & $0,4 \pm 0,8$ & $0,4 \pm 0,8$ & $0,4 \pm 0,5$ \\
\hline Kontrol Negatif & $9,6 \pm 1,14$ & $10,2 \pm 0,8$ & $9,8 \pm 4,5$ & $12,2 \pm 2,1$ & $11 \pm 1,2$ & $9,2 \pm 2,5$ \\
\hline Dosis ekstrak $450 \mathrm{mg}$ & $1,8 \pm 2,4$ & $2,8 \pm 4,7$ & $2,6 \pm 2,7$ & & $4,4 \pm 3,3$ & $1,8 \pm 2,9$ \\
\hline Dosis ekstrak $500 \mathrm{mg}$ & $0,4 \pm 0,5$ & $0,2 \pm 0,4$ & $0,4 \pm 0,5$ & & $0,4 \pm 0,8$ & $0,4 \pm 0,5$ \\
\hline Dosis ekstrak $550 \mathrm{mg}$ & $0 \pm 0$ & $1 \pm 2,2$ & $0,2 \pm 0,4$ & $0,4 \pm 0,5$ & $0,2 \pm 0,4$ & $0 \pm 0$ \\
\hline
\end{tabular}

Berdasarkan tabel 2. Menunjukkan bahwa rata-rata pengukuran geliat mencit paling besar terdapat pada kontrol negatif dibandingkan kelompok yang lain sedangkan kelompok yang memiliki rata-rata geliat paling kecil yaitu kontrol positif dan dosis ekstrak $550 \mathrm{mg} / \mathrm{kgBB}$. Hal tersebut disebabkan karena pada kontrol positif terdapat zat aktif berupa asetosal yang memiliki aktivitas sebagai analgesik dengan mekanisme kerja menghambat biosintesis prostaglandin melalui penghambatan aktivitas enzim cyclooxigenase (COX) (Tamimi et al., 2020). Sedangkan pada dosis ekstrak memiliki kandungan senyawa flavonoid yang bekerja sebagai analgesik dalam mengurangi rasa nyeri selain itu flavonoid juga menghambat degranulasi neutrofil sehingga akan menghambat pengeluaran sitokin, radikal bebas, serta enzim yang berperan dalam peradangan (Sentat \& Pangestu, 2017).

\begin{tabular}{cc}
\multicolumn{1}{c}{$\begin{array}{c}\text { Tabel 3. } \\
\text { analgesik }\end{array}$} & $\begin{array}{c}\text { Data Persen daya } \\
\text { Kelompok }\end{array}$ \\
\hline Kontrol + & \% Daya Analgesik \\
Kontrol - & 98 \\
Ekstrak 450mg/kg BB & 0 \\
Ekstrak 500mg/kg BB & 71 \\
Ekstrak 550mg/kg BB & 96,77 \\
\hline
\end{tabular}

Tabel 3. menunjukkan bahwa dari ke-5 kelompok perlakuan yang memiliki persen daya analgesik tertinggi yaitu kelompok kontrol positif dan yang memiliki daya analgesik terendah yaitu kelompok kontrol negatif. Sedangkan untuk kelompok perlakuan dosis ekstrak menunjukkan semakin tinggi dosis, maka persen daya analgesiknya semakin besar.
Selanjutnya analisis data menggunakan uji statistik, data tersebut diuji normalitas untuk mengetahui data tersebut terdistribusi normal atau tidak menggunakan uji Shapiro Wilk. Data yang dianalisis menunjukkan tidak terdistribusi normal dimana nilai sig $<0.05$ sehingga data dilakukan analisis selanjutnya menggunakan Kruskal Wallis. Hasil analisis menunjukkan adanya perbedaan bermakna antara kelompok negative dengan kelompok perlakuan dosis ekstrak $400 \mathrm{mg}, 500 \mathrm{mg}$, $550 \mathrm{mg}$ dan kontrol positif. Hal tersebut disebabkan karena pada kontrol negative tidak terdapat zat aktif yang memiliki aktivitas analgesik. Sedangkan pada kelompok perlakuan dosis ekstrak dan kontrol positif memberikan pengaruh yang besar dalam menurunkan rasa nyeri, dan pengaruh pemberian ekstrak dalam menurunkan rasa nyeri hampir sama dengan kontrol positif.

3.4. Hasil pemeriksaan makroskopis lambung mencit

Hasil dari pemeriksaan kontrol negative menunjukkan bahwa tidak tampak adanya iritasi pada mukosa lambung berupa bintik berdarah maupun erosi pada permukaan lapisan mukosa lambung. Sedangkan pada kelompok kontrol positif, tampak adanya iritasi pada mukosa lambung berupa bintik berdarah. Hasil indeks tukak yang diperoleh dapat dilihat pada tabel 4 .

Tabel 4. Data Indeks Tukak Lambung

\begin{tabular}{cc}
\multicolumn{2}{c}{ Lambung } \\
\hline Kelompok & Indeks Tukak \\
\hline Kontrol positif & 16,4 \\
Kontrol negatif & 2 \\
Ekstrak 450mg/kgBB & 2 \\
Ekstrak 500mg/kgBB & 2 \\
Ekstrak 550mg/kgBB & 4,6 \\
\hline
\end{tabular}




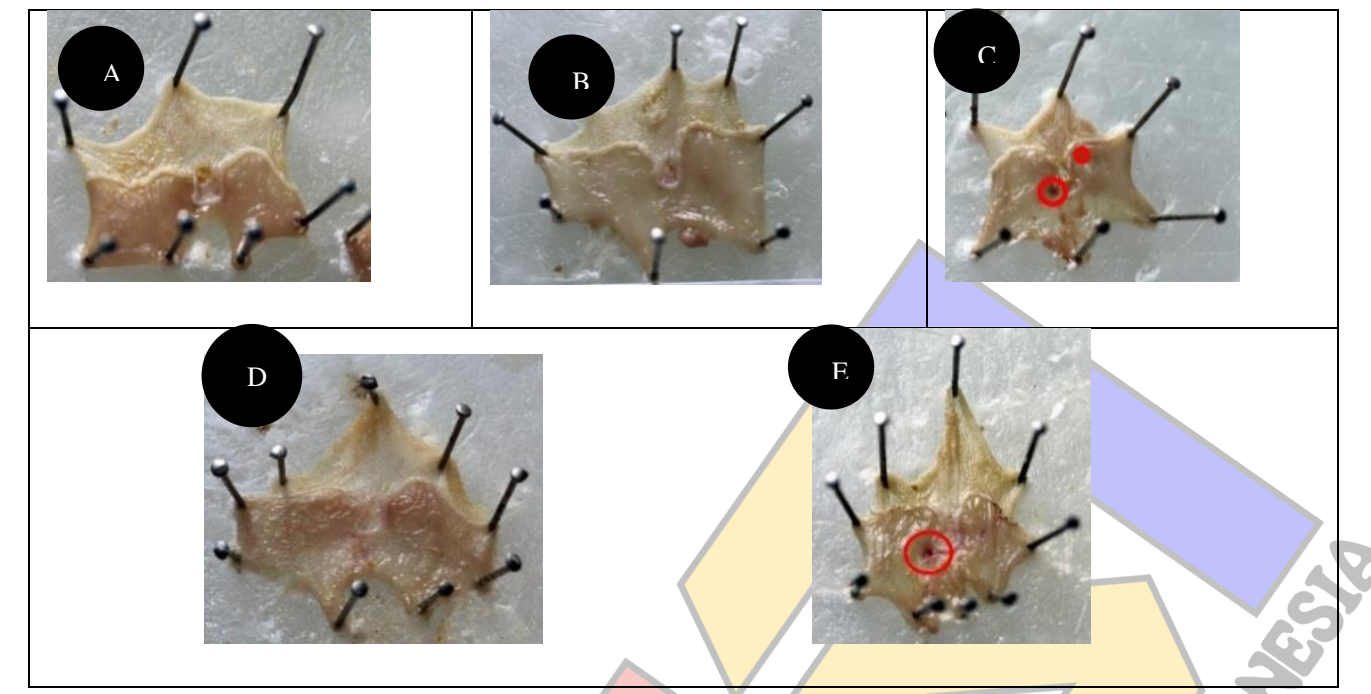
Keterangan:
a. kelompok kontrol negatif
b. kelompok kontrol positif
c. kelompok ekstrak $450 \mathrm{mg} / \mathrm{KgBB}$
d. kelompok ekstrak 500mg/KgBB
e. kelompok ekstrak 550mg/KgBB

Dari data tabel 4 dapat diartikan bahwa nilai indeks tukak pada kontrol positif memiliki nilai yang paling tinggi, yaitu 16,4 sedangkan untuk kontrol perlakuan Ekstrak 450mg/kgBB, Ekstrak $500 \mathrm{mg} / \mathrm{kgBB}$ dan Kontrol negatif mendapatkan indeks tukak 2, sedangkan untuk dosis Ekstrak $550 \mathrm{mg} / \mathrm{kgBB}$ mendapatkan nilai 4,6 .

Setelah dilakukan analisis lanjutan menggunakan statistik Kruskal-Wallis dan MannWhitney. Indeks tukak kontrol positif $(16,4)$, kontrol negatif, dosis ekstrak $450 \mathrm{mg} / \mathrm{kg} \mathrm{BB}$, dan dosis ekstrak $500 \mathrm{mg} / \mathrm{kg}$ BB sama, yaitu (2), sedangkan pada dosis ekstrak $550 \mathrm{mg} / \mathrm{kg}$ BB $(4,6)$. Hal ini menunjukkan bahwa pada dosis ekstrak $550 \mathrm{mg} / \mathrm{kg}$ BB memiliki efek samping pada lambung, sama halnya dengan kontrol positif, namun efek samping yang ditimbulkan oleh dosis ekstrak $550 \mathrm{mg} / \mathrm{kg}$ BB tidak separah kontrol positif karena dilihat dari data di atas bahwa nilai indeks tukak kontrol positif lebih besar daripada dosis ekstrak 550mg/kg BB dan juga dari segi gambar lambung yang ada menunjukkan skor keparahan dan skor jumlah tukak lebih banyak terjadi pada lambung kontrol positif. Kontrol positif diberikan bahan uji berupa asetosal yang memiliki efek samping terhadap lambung sehingga perlindungan terhadap mukosa lambung semakin menurun karena disebabkan oleh penghambatan enzim siklooksigenase yang berpengaruh terhadap penghambatan prostasiklin yang berperan dalam melindungi mukosa lambung (Dipiro, 2015).

\section{Kesimpulan}

Berdasarkan hasil penelitian dan analisis data yang dilakukan maka dapat diambil kesimpulan:

1. Ekstrak etanol herba dandang gendis (Clinacanthus nutans (Burm f.) Lindau) memiliki aktivitas sebagai analgesik terhadap mencit jantan dengan metode writhing test.

2. Ekstrak herba dandang gendis (Clinacanthus nutans (Burm f.) Lindau) dengan dosis $500 \mathrm{mg} / \mathrm{kgBB}$ merupakan dosis yang paling efektif digunakan sebagai analgesik.

3. Ekstrak etanol dandang gendis (Clinacanthus nutans (Burm f.) Lindau) aman digunakan sebagai analgesik dengan dosis $500 \mathrm{mg} / \mathrm{kgBB}$.

\section{Daftar Pustaka}

Amellia, G., \& Khumaidi, A. (2015). UJI EFEK ANALGETIKA EKSTRAK BUAH KAKTUS ( Opuntia elatior Mill .) PADA MENCIT ( Mus 
musculus ) YANG DIINDUKSI ASAM ASETAT ANALGETICS EFFECT OF CACTUS FRUITS EXTRACT ( Opuntia elatior Mill .) ON ACETIC ACID INDUCED MICE (Mus musculus ). Journal of Pharmacy 1(1), 16-21.

Dewinta, N. R., Mukono, I. S., \& Mustika, A. (2020). Pengaruh Pemberian Ekstrak Dandang Gendis (Clinacanthus nutans) Terhadap Kadar Glukosa Darah pada Tikus Wistar Model Diabetes Melitus. Jurnal Medik Veteriner, 3(1), 76. https://doi.org/10.20473/jmv.vol3.iss1.2020. 76-81

DiPiro J.T., Wells B.G., Schwinghammer T.L. and DiPiro C. V.,. (2015). Pharmacotherapy Handbook, Ninth Edit., McGraw-Hill Education Companies, Inggris.

Fadhilla, G., Adnyana, I. ., \& Chaniago, R. (2020). Analgetic Activity of Ethanol Extract of Ciplukan Leaves (Physalis peruviana L .) on Male Swiss Webster Mice by Stretching Method (Sigmund). Jurnal Ilmiah Farmako Bahari, 11(1), 75-88.

Mai, C. W., Yap, K. S. I., Kho, M. T., Ismail, N. H., Yusoff, K., Shaari, K., ... Lim, E. S. H. (2016). Mechanisms underlying the antiinflammatory effects of Clinacanthus nutans lindau extracts: Inhibition of cytokine production and toll-like receptor-4 activation. Frontiers in Pharmacology, 7(FEB), 1-11. https://doi.org/10.3389/fphar.2016.00007

Mashuri Yusuf, Lilik Koernia Wahidah, Subur Widodo, Puspita Gita Sari, \& Mohammad Kanedi. (2020). Analgesic activity of the combined extract of sukun (Artocarpus altilis) and melinjo (Gnetum gnemon L.) Leaves in mice. GSC Biological and Pharmaceutical Sciences, 13(1), 244-250. https://doi.org/10.30574/gscbps.202013.1.34 4

Murugesu, S., Ibrahim, Z., Ahmed, Q. U., Yusoff, N. I. N., Uzir, B. F., Perumal, V., ... Khatib, A. (2018). Characterization of?-glucosidase inhibitors from clinacanthus nutans lindau leaves by gas chromatography-mass spectrometry-based metabolomics and molecular docking simulation. Molecules, 23(9). https://doi.org/10.3390/molecules23092402
Patel, J. M. (2010). A Review of Potential Health Benefits of Flavonoids A Review of Potential Health Benefits of Flavonoids Table of Contents Major classes and Food sources of flavonoids A Review of Potential Health Benefits of Flavonoids Free radicals. Lethbridge Undergraduate Research Journal, 3, 2-6.

Rustam, E., \& Arifin, H. (2020). Efek Analgetik Ekstrak Etanol Daun Kemangi (Ocimum sanctum L.) Pada Mencit Putih Jantan. Jurnal Farmasi Higea, 12(1), 40-47. Retrieved from http://www.jurnalfarmasihigea.org/index.php /higea/article/view/262

Sentat, T,, \& Pangestu, S. (2017). UJI EFEK ANALGESIK EKSTRAK ETANOL DAUN KERSEN/Muntingia calabura L.) PADA MENCIT PUTIH JANTAN (Mus musculus) DENGAN INDUKSI NYERI ASAM ASETAT. Jurnal Ilmiah Manuntung, 2(2), 147. https://doi.org/10.51352/jim.v2i2.59

Tambaru, E., Paembonan, S. A., Ura', R., \& Tuwo, M. (2019). Analisis Anatomi dan Trikoma Tanaman Obat Dandang Gendis Clinacanthus nutans (Burm. f.) Lindau. Jurnal Ilmu Alam Dan Lingkungan, 10(1), 35-41. https://doi.org/10.20956/jal.v10i1.6556

Tamimi, A. A. P., Queljoe, E. de, \& Siampa, J. P. (2020). Uji efek analgesik ekstrak etanol daun kelor(Moringa oleifera Lam.) pada tikus putih jantan galur wistar (Rattus norvegicus). Pharmacon, 9(3), 325-333. Retrieved from https://ejournal.unsrat.ac.id/index.php/pharm acon/article/view/30015

Wijaya, S., Setiawan, H. K., \& Purnama, V. B. (2019). Standarisasi Spesifik dan Non Spesifik dari Ekstrak Etanol Daun dandang Gendis (Clinacanthus nutans). Jurnal Farmasi Sains Dan Terapan, 6(2), 56-65. Retrieved from http://journal.wima.ac.id/index.php/JFST/arti cle/view/2224 